\title{
An investigation of expectations of urban forest users: Example of Western Black Sea Region
}

\author{
Fatma ÇíNİS, Erdoğan ATMIş, H. Batuhan GÜNŞEN* \\ Bartın University, Faculty of Forestry, Bartın, TURKEY \\ *Corresponding author: hgunsen@bartin.edu.tr
}

Received Date: 09.01.2017

Accepted Date: 12.05.2017

\begin{abstract}
Aim of study: The data on to what extend the urban forests, whose numbers have currently reached 133, meet the expectations of the society is insufficient. Whereas, the views of the urban forest users and the remaining non-user public are very important in governing of urban forests. The aim of this study is to determine the user characteristics and usage patterns of three urban forests in the Western Black Sea Region, and to find out about the expectations of the users from the urban forests.

Area of study: This study was conducted at the Bartın, Karabük, and Safranbolu urban forests in Western Black Sea Region of Turkey.

Material and Methods: Within the scope of the study, field visits to Bartın, Karabük and Safranbolu urban forests were carried out, during which the concerned parties were interview and notes were taken; and, to help determine the characteristics of the urban forest users, a survey consisting of 29 questions -including one open-ended question- was carried out face-to-face in each urban forest with a total 180 individuals, 60 of which were users. Data acquired have been evaluated by means of frequency and percentage analysis.

Main results: In the study, it was revealed that the users generally perceive the urban forests as areas for picnicking or as areas that provide clean air. A significant part of the users consider that the selection of the locations for the urban forest were carried out correctly. Almost half of the users surveyed state that they were not happy with how the urban forests are managed.

Research highlights: The perceptions and thoughts of the urban forest users regarding the resource they are utilizing shape their demands from these areas. Identification of the expectations of the users and satisfaction of those expectations will both increase the quality of services provided in urban forests and the level of success in the governance of urban forests.
\end{abstract}

Keywords: Western Black Sea, Urban forestry, recreation, demand, green infrastructure

\section{Kent ormanı kullanıcılarının beklentileri üzerine bir araştırma: Batı}

\section{Karadeniz Bölgesi örneği}

\section{Özet}

Çalışmanın amacı: Günümüzde sayısı 133'e ulaşan kent ormanlarının; halkın beklentilerini hangi ölçüde karşıladığına ilişkin veriler yetersizdir. Oysa kent ormanlarının yönetiminde kent ormanı kullanıcılarının ve kullanıcılar dışında kalan halkın düşünceleri çok önemlidir. Bu çalışmanın amacı Batı Karadeniz Bölgesi'nde bulunan üç kent ormanının kullanıcı özelliklerini ve kullanım şekillerini tespit etmek ve kullanıcıların kent ormanlarından beklentilerini öğrenmektir.

Çalışma alanı: Bu çalışma Türkiye'nin Batı Karadeniz Bölümünde yer alan Bartın, Karabük ve Safranbolu kent ormanlarında yürütülmüştür.

Materyal ve Yöntem: Araştırma kapsamında Bartın, Karabük ve Safranbolu kent ormanlarında incelemeler yapılarak, ilgililerle görüșülmüș, alınan notlar ve literatür araștırması ile kent ormanı kullanıcılarının özelliklerini belirlemeye yardımcı olacak biri açık uçlu olmak üzere 29 sorudan oluşan bir anket, her bir kent ormanında 60 kullanıcı olmak üzere toplam 180 kişi ile yüz yüze görüşülerek uygulanmıştır. Elde edilen veriler frekans ve yüzde analizi yardımı ile değerlendirilmiştir.

Sonuçlar: Yapılan çalışmada, kullanıcıların kent ormanlarını genellikle piknik yapılan ve temiz hava sağlayan bir alan olarak algıladıkları tespit edilmiştir. Kullanıcıların önemli bir kısmı kent ormanlarının kurulduğu yerlerin seçiminin doğru yapıldığını düşünmektedir. Görüşülen kullanıcıların nerdeyse yarıya yakını kent ormanlarının yönetiminden memnun olmadıklarını da dile getirmiş̧lerdir.

Araştırma vurguları: Kent ormanı kullanıcılarının yararlandıkları kaynakla ilgili algıları ve düşünceleri bu alanlardan olan taleplerini şekillendirmektedir. Kullanıcıların beklentilerinin tespiti ve bu beklentilerin tatmini, hem kent ormanlarında verilen hizmetin kalitesini, hem de kent ormanlarının yönetimindeki başarıyı artıracaktır.

Anahtar Kelimeler: Batı Karadeniz, Kent ormancıllğı, Rekreasyon, Talep, Yeşil altyapı 


\section{Introduction}

There has been a significant increase in the ratio of the population living in the cities in Turkey, while the ratio of the population living in rural areas has been decreasing due to internal migration. According to the data from Turkish Statistical Institute, as of 2015, $92.1 \%$ of country's population is living in the cities. Such exchange of population between the rural areas and the cities has been both increasing and diversifying the expectations of urban dwellers from recreation areas, open green spaces, and urban forests (Atmiş et al., 2007, p. 90).

Urban forests are established to satisfy particularly non-material demands of the people living in the cities from forests. Primarily for the people living in the cities, and the society in general, urban forests provide a variety of benefits, such as, decreasing the noise pollution in the cities (Uzun et al., 2007, p. 355), regulating the urban temperatures (Kuo and Sullivan, 2001, p. 543), capturing and storing of carbon emissions (Zhao et al., 2010, p. 807), positively contributing to the physical and psychological development of children especially (Taylor et al., 1998, p. 3; UEI, 2008, p. 7), and increasing air quality and preventing storms in the cities (Zhu and Zhang, 2008, p. 293). These ecosystem services contribute to the development of environmental quality, quality of life, and sustainable urban governance.

The first time when the urban forests have been mentioned in the development plans in Turkey was in Long-Term Strategy and Eighth Five Year Development Plan (20012005). Although not in detail, the plan did list "set up in the form of green belts and parks, promoting and popularizing urban forests and memorial forests for social, cultural, and environmental purposes, and with the aim of reducing the social pressure on natural forests" among the targets for the nation's forestry (SPO, 2000, p. 141). In order to satisfy those provisions included in the development plan listed for General Directorate of Forestry (GDF), with the aim of satisfying recreational demands of urban population from forests, urban forests have been started to be established in 2003 in provinces and large districts (GDF, 2003, p.
3 ), and, their numbers have currently reached 133 (GDF, 2016).

A more detailed assessment could suggest that, in Turkey, urban forests have started to be established with the aim of putting their health, exercise, aesthetics, cultural, and social functions to use, for promoting technical forestry activities along with flora and fauna, and for educating children and youth in particular about nature (Atmiş and Günşen, 2015, p. 246; Atmiş et al., 2015a, p. 7; Atmiş et al., 2015b, p. 16). However, in time the practices have fallen behind those targets. Because the urban forests were established too rapidly and without planning, they have become a little-known establishment, which is poorly managed -or even not managed at all- and under-utilized, as in for picnicking (Atmiş et al., 2007, p. 89; Atmiş et al., 2011, p. 87; Atmiş et al., 2012, p. 69; Atmiş, 2016, p. 158; Atmiş et al., 2017, p. 8).

It is stated that, the establishment criteria for urban forests are inadequate, and the demands and basic needs of urban dwellers are not considered during this process (Çağlar, 2004, p. 472). Today, the data on to which degree the expectations of the society from urban forests are satisfied is still insufficient. There are only but a limited number of studies on this subject. Yet, the considerations of the urban forest users and the rest of the society is critical for the governance of urban forests. Determining the expectations of the users and satisfying those expectations would increase both the level of service quality and the governance success rate in urban forests (Atmiş, 2016, p. 158). For instance, Tolunay et al. (2004) states that, because it contains a wealth of information on the nature and the characteristics of the demands from urban forests, the identification of user profiles should shape the planning efforts (p. 137).

The aim of this study is to reveal the user characteristics and the usage forms of Bartın, Karabük, and Safranbolu urban forests in the Western Black Sea Region, and to analyze the expectations of the users from urban forests. 


\section{Material and Methods}

As of 2016, the number of urban forests that were started to be established by General Directorate of Forestry though One Urban Forest for Every Province Project initiated in 2003 have reached 133, of which 103 is in the provinces and 30 is in the districts. The total area of urban forests is 10314.5 hectares and their average size is 77.55 hectares (GDF, 2016).

Bartın, Karabük, and Safranbolu urban forests located in the Western Black Sea Region have been selected as the study area (Figure 1). All three urban forests are placed under the authority of Zonguldak Regional Directorate of Forestry.

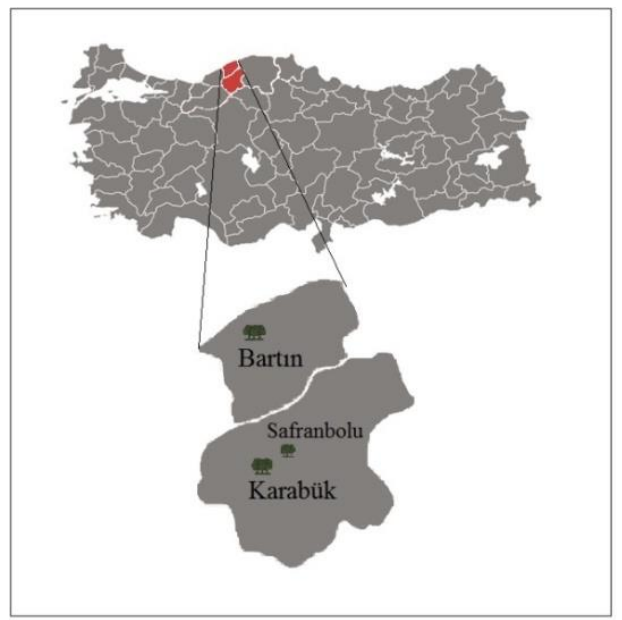

Figure 1. Study area.

Established in 2010, Bartın Urban Forest is adjacent to the city and covers an area of 18.7 hectares. Karabük Urban Forest was established in 2005. Among the urban forests included in the study, it is the closest one to the city center and its area is 37.42 hectares. Safranbolu Urban Forest was established in 2006. It is located $3 \mathrm{~km}$ away from the city center in Bağlar area and covers an area of 284.9 hectares.
In the study, a detailed literature review, which included researching national and international studies on urban forests and their users, has been carried out. Then, by visiting Zonguldak Regional Directorate of Forestry, which is the authority in charge of the urban forests selected as sample, interviews were conducted with administrative and technical staff of forestry organization and establishment files of the urban forests have been reviewed in detail.

A survey consisting of 29 questions -28 closed ended and 1 open ended- was prepared to determine the characteristics and expectations of the users of the three urban forests selected as sample. A total of 180 persons -60 from each urban forest- were surveyed face-to-face between June 11 and October 11, 2014. 33.89\% of those surveyed consisted of young individuals between the ages of 20 and 34 . When the level of education was assessed, it was observed that almost half of the users were found to be graduates of higher education (Table 1). The survey was intentionally conducted during both working days and weekends and during the summer months when the number of users peak. During visits to conduct the survey, the manner the users utilize the urban forests, and the facilities and the activities in the urban forests were observed, photographed, and noted. The raw data from survey was then evaluated in terms of frequencies and percentages. The characteristics of the urban forest users and their thoughts regarding the urban forests were attempted to be revealed according to the conclusions from the survey and the observations made. The detailed data regarding the study can be found in the master's thesis "An Investigation of User Characteristics in the Urban Forests in West Black Sea Region" (Çinis, 2016, pp. 26-118).

Table 1. Selected User Characteristics

\begin{tabular}{|c|c|c|c|c|c|c|c|c|}
\hline \multicolumn{2}{|c|}{ Characteristics } & Fr & $\%$ & & Characteristics & & $\mathbf{F r}$ & $\%$ \\
\hline \multirow{2}{*}{ لَّ } & Female & 91 & 50.56 & \multirow{7}{*}{ 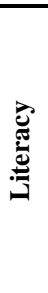 } & Illiterate & & 1 & 0.56 \\
\hline & Male & 89 & 49.44 & & Primary School & & 24 & 13.33 \\
\hline \multirow{5}{*}{ 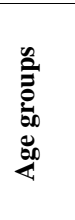 } & -19 & 32 & 17.78 & & Primary Education & & 5 & 2.78 \\
\hline & $20-34$ & 61 & 33.89 & & Middle School & & 8 & 4.44 \\
\hline & $35-49$ & 52 & 28.89 & & High school or equiv. & & 54 & 30.00 \\
\hline & $50-64$ & 30 & 16.67 & & College or higher & & 88 & 48.89 \\
\hline & $65+$ & 5 & 2.78 & & & Total & 180 & 100.00 \\
\hline
\end{tabular}




\section{Results and Discussion}

Perception of urban forest

When asked about the urban forest, users stated that the first thing that comes to their mind is a picnic area (17.78\%), clean air $(15 \%)$, a green area $(12.22 \%)$, a forest area $(11.67 \%)$, and a natural environment $(11.11 \%)$ (Table 2). Even when the three urban forests are evaluated separately, no significant differences were observed in the users' perceptions of urban forests. In a similar study where the perception of urban forest was investigated, it was also determined that the urban forests were described as natural or man-made areas that are located within or at the periphery of the city, and that they provided recreation opportunities and contributed to the urban structure in an aesthetic and functional way (Kiper and Öztürk, 2011, p. 105).

Table 2. Users' Perception of Urban Forest

\begin{tabular}{lrrrrrrrr}
\hline \multirow{2}{*}{ Perception } & \multicolumn{2}{c}{ Bartın UF } & \multicolumn{2}{c}{ Karabük UF } & Safranbolu UF & \multicolumn{2}{c}{ Total } \\
\cline { 2 - 10 } & Fr & \% & Fr & \% & Fr & \% & Fr & \% \\
\hline Picnic area & 10 & 16.67 & 9 & 15.00 & 13 & 21.67 & 32 & 17.78 \\
\hline Clean air & 12 & 20.00 & 6 & 10.00 & 9 & 15.00 & 27 & 15.00 \\
\hline Green area & 4 & 6.67 & 8 & 13.33 & 10 & 16.67 & 22 & 12.22 \\
\hline Forest area & 12 & 20.00 & 6 & 10.00 & 3 & 5.00 & 21 & 11.67 \\
\hline Natural environment & 8 & 13.33 & 4 & 6.67 & 8 & 13.33 & 20 & 11.11 \\
\hline Trees & 5 & 8.33 & 4 & 6.67 & 4 & 6.67 & 13 & 7.22 \\
\hline Tranquil setting & 8 & 13.33 & 4 & 6.67 & 0 & 0 & 12 & 6.67 \\
\hline Peace & 1 & 1.67 & 2 & 3.33 & 6 & 10.00 & 9 & 5.00 \\
\hline Close to the city & 2 & 3.33 & 3 & 5.00 & 2 & 3.33 & 7 & 3.89 \\
\hline Walking & 4 & 6.67 & 2 & 3.33 & 0 & 0 & 6 & 3.33 \\
\hline Recreation & 1 & 1.67 & 2 & 3.33 & 3 & 5.00 & 6 & 3.33 \\
\hline Exercising & 1 & 1.67 & 5 & 8.33 & 0 & 0 & 6 & 3.33 \\
\hline Place to rest & 1 & 1.67 & 1 & 1.67 & 3 & 5.00 & 5 & 2.78 \\
\hline Pine grove & 2 & 3.33 & 2 & 3.33 & 1 & 1.67 & 5 & 2.78 \\
\hline Fun & 1 & 1.67 & 0 & 0 & 1 & 1.67 & 2 & 1.11 \\
\hline Animals & 1 & 1.67 & 0 & 0 & 1 & 1.67 & 2 & 1.11 \\
\hline Outing area & 0 & 0 & 2 & 3.33 & 0 & 0 & 2 & 1.11 \\
\hline Cafeteria & 0 & 0 & 2 & 3.33 & 0 & 0 & 2 & 1.11 \\
\hline Oxygen & 0 & 0 & 1 & 1.67 & 1 & 1.67 & 2 & 1.11 \\
\hline Conservation area, living area & 0 & 0 & 2 & 3.33 & 0 & 0 & 2 & 1.11 \\
\hline Mushroom & 0 & 0 & 0 & 0 & 2 & 3.33 & 2 & 1.11 \\
\hline Picnicking without barbecue & 0 & 0 & 0 & 0 & 2 & 3.33 & 2 & 1.11 \\
\hline Dump site & 0 & 0 & 1 & 1.67 & 0 & 0 & 1 & 0.56 \\
\hline Barbecuing & 0 & 0 & 1 & 1.67 & 0 & 0 & 1 & 0.56 \\
\hline Recreation area & 1 & 1.67 & 0 & 0 & 0 & 0 & 1 & 0.56 \\
\hline & & & & & & & & \\
\hline
\end{tabular}

Location and characteristics of urban forest

When urban forest is mentioned, the first thing that the users think of is a place to picnic. Nevertheless, $56.67 \%$ of the users do mention that the urban forests are different from recreation areas (Table 3).

Table 3. Difference between urban forests and other recreation areas

\begin{tabular}{rrrrrrrrr}
\hline \multirow{2}{*}{ Difference } & \multicolumn{2}{c}{ Bartın UF } & \multicolumn{2}{c}{ Karabük UF } & \multicolumn{2}{c}{ Safranbolu UF } & \multicolumn{2}{c}{ Total } \\
\cline { 2 - 9 } & Fr & $\mathbf{\%}$ & Fr & \% & Fr & \% & Fr & $\%$ \\
\hline Exists & 34 & 56.66 & 34 & 56.66 & 34 & 56.66 & 102 & 56.67 \\
\hline Partially exists & 2 & 3.33 & 16 & 26.66 & 3 & 5.00 & 21 & 11.67 \\
\hline Does not exist & 24 & 40.00 & 10 & 16.66 & 23 & 38.33 & 57 & 31.67 \\
\hline \multicolumn{1}{c}{ TOTAL } & $\mathbf{6 0}$ & $\mathbf{1 0 0}$ & $\mathbf{6 0}$ & $\mathbf{1 0 0}$ & $\mathbf{6 0}$ & $\mathbf{1 0 0}$ & $\mathbf{1 8 0}$ & $\mathbf{1 0 0}$ \\
\hline
\end{tabular}


$71.67 \%$ of the users stated that the locations of urban forests within the city were convenient (Table 4). Even when the urban forests are evaluated separately, the users that expressed satisfaction with the location of urban forests were in majority. However, in Karabük Urban Forest, a higher percentage of users $(33.33 \%)$ thought that the location of the urban forest was inconvenient.

Table 4. Convenience of urban forests' locations

\begin{tabular}{crrrrrrrr}
\hline \multirow{2}{*}{ Convenience } & \multicolumn{2}{c}{ Bartın UF } & \multicolumn{2}{c}{ Karabük UF } & \multicolumn{2}{c}{ Safranbolu UF } & \multicolumn{2}{c}{ Total } \\
\cline { 2 - 10 } & Fr & $\mathbf{\%}$ & Fr & \% & Fr & \% & Fr & \% \\
\hline Not convenient & 5 & 8.33 & 20 & 33.33 & 7 & 11.66 & 32 & 17.78 \\
\hline Doesn't matter & 7 & 11.66 & 12 & 20.00 & 0 & 0 & 19 & 10.56 \\
\hline Convenient & 48 & 80.00 & 28 & 46.66 & 53 & 88.33 & 129 & 71.67 \\
\hline \multicolumn{1}{c}{ TOTAL } & $\mathbf{6 0}$ & $\mathbf{1 0 0}$ & $\mathbf{6 0}$ & $\mathbf{1 0 0}$ & $\mathbf{6 0}$ & $\mathbf{1 0 0}$ & $\mathbf{1 8 0}$ & $\mathbf{1 0 0}$ \\
\hline
\end{tabular}

An overwhelming $92.22 \%$ of users surveyed considered the urban forest as a part of the city they lived in (Table 5). These results show that the urban forests have become integrated with the city and the users have adopted the urban forests.

Table 5. Urban forest - city relationship

\begin{tabular}{crrrrrrrr}
\hline \multirow{2}{*}{ Belonging } & \multicolumn{2}{c}{ Bartın UF } & \multicolumn{2}{c}{ Karabük UF } & \multicolumn{2}{c}{ Safranbolu UF } & \multicolumn{2}{c}{ Total } \\
\cline { 2 - 10 } & Fr & $\mathbf{\%}$ & Fr & \% & Fr & \% & Fr & \% \\
\hline Not part of city & 2 & 3.33 & 0 & 0 & 1 & 1.67 & 3 & 1.67 \\
\hline Partially related to city & 2 & 3.33 & 5 & 8.33 & 4 & 6.67 & 11 & 6.11 \\
\hline A part of city & 56 & 93.33 & 55 & 91.67 & 55 & 91.67 & 166 & 92.22 \\
\hline TOTAL & $\mathbf{6 0}$ & $\mathbf{1 0 0}$ & $\mathbf{6 0}$ & $\mathbf{1 0 0}$ & $\mathbf{6 0}$ & $\mathbf{1 0 0}$ & $\mathbf{1 8 0}$ & $\mathbf{1 0 0}$ \\
\hline
\end{tabular}

\section{Perspective on nature and child development}

When it was questioned whether or not the perspective of the users on trees, forests, and animals has changed, $55.56 \%$ stated that they already had such perspective, thus, visiting the urban forest did not have an impact on their views. On the other hand,
$40.56 \%$ of the users stated that their views were positively affected (Table 6). Sandal and Karademir (2013) had asked the users about the impact of green areas on establishing urban identity and organizing urban aesthetics, and 95\% of the users had reported views towards significant contributions (p. 169).

Table 6. Impact of urban forest on perspective on nature

\begin{tabular}{crrrrrrrr}
\hline \multirow{2}{*}{$\begin{array}{c}\text { Impact on perspective } \\
\text { on nature }\end{array}$} & \multicolumn{2}{c}{ Bartın UF } & \multicolumn{2}{c}{ Karabük UF } & \multicolumn{2}{c}{ Safranbolu UF } & \multicolumn{2}{c}{ Total } \\
\cline { 2 - 10 } & Fr & \% & Fr & \% & Fr & \% & Fr & \% \\
\hline Changed negatively & 4 & 6.67 & 2 & 3.33 & 1 & 1.67 & 7 & 3.89 \\
\hline Did not change & 35 & 58.33 & 27 & 45.00 & 38 & 63.33 & 100 & 55.56 \\
\hline Changed positively & 21 & 35.00 & 31 & 51.67 & 21 & 35.00 & 73 & 40.56 \\
\hline TOTAL & $\mathbf{6 0}$ & $\mathbf{1 0 0}$ & $\mathbf{6 0}$ & $\mathbf{1 0 0}$ & $\mathbf{6 0}$ & $\mathbf{1 0 0}$ & $\mathbf{1 8 0}$ & $\mathbf{1 0 0}$ \\
\hline
\end{tabular}

$90.56 \%$ of users stated that organizing education on nature in urban forests would positively impact physical and mental development of children (Table 7). Also according to the report prepared by Boston Urban Ecology Institute (U.S.A.), it was mentioned that the trees and green areas that are in the vicinity of residential and play areas reduced the symptoms of Attention Deficit Hyperactivity Disorder (ADHD) in children and enhance mental skills of children (Taylor et al., 1998, p. 3; UEI, 2008, p. 5). 
Table 7. Contribution of urban forest to child development

\begin{tabular}{lrrrrrrrr}
\hline \multirow{2}{*}{ Contribution to child development } & \multicolumn{2}{c}{ Bartın UF } & \multicolumn{2}{c}{ Karabük UF } & \multicolumn{2}{c}{ Safranbolu UF } & \multicolumn{2}{c}{ Total } \\
\cline { 2 - 10 } & Fr & \% & Fr & \% & Fr & \% & Fr & \% \\
\hline Does not contribute & 1 & 1.67 & 1 & 1.67 & 6 & 10.00 & 8 & 4.44 \\
\hline Nothing changes & 6 & 10.00 & 1 & 1.67 & 2 & 3.33 & 9 & 5.00 \\
\hline Contributes & 53 & 88.33 & 58 & 96.67 & 52 & 86.67 & 163 & 90.56 \\
\hline \multicolumn{1}{c}{ TOTAL } & $\mathbf{6 0}$ & $\mathbf{1 0 0}$ & $\mathbf{6 0}$ & $\mathbf{1 0 0}$ & $\mathbf{6 0}$ & $\mathbf{1 0 0}$ & $\mathbf{1 8 0}$ & $\mathbf{1 0 0}$ \\
\hline
\end{tabular}

\section{Visiting season preferences}

$43.33 \%$ of the people surveyed said they preferred visiting the urban forests in the summer months and as opposed to $16.67 \%$ in the spring. $36.67 \%$ of the surveyed expressed that they use the urban forests in every season. While Bartın Urban Forest was found out to be used intensively every season, Karabük and Safranbolu urban forests are found to be used during the summer season (Table 8). Similarly, Kurdoğlu and Düzgüneş (2011) determined that $88 \%$ of Artvin Urban Forest users prefered the summer months (p. 204).

Table 8 . Seasons preferred by users

\begin{tabular}{lrrrrrrrr}
\hline \multirow{2}{*}{ Seasons } & \multicolumn{2}{c}{ Bartın UF } & \multicolumn{2}{c}{ Karabük UF } & \multicolumn{2}{c}{ Safranbolu UF } & \multicolumn{2}{c}{ Total } \\
\cline { 2 - 10 } & Fr & $\mathbf{\%}$ & Fr & $\mathbf{\%}$ & Fr & \% & Fr & \% \\
\hline Spring & 9 & 15.00 & 8 & 13.33 & 13 & 21.67 & 30 & 16.67 \\
\hline Summer & 21 & 35.00 & 25 & 41.67 & 32 & 53.33 & 78 & 43.33 \\
\hline Autumn & 0 & 0 & 4 & 6.67 & 2 & 3.33 & 6 & 3.33 \\
\hline Winter & 0 & 0 & 0 & 0 & 0 & 0 & 0 & 0 \\
\hline All seasons & 30 & 50.00 & 23 & 38.33 & 13 & 21.67 & 66 & 36.67 \\
\hline \multicolumn{1}{c}{ TOTAL } & $\mathbf{6 0}$ & $\mathbf{1 0 0}$ & $\mathbf{6 0}$ & $\mathbf{1 0 0}$ & $\mathbf{6 0}$ & $\mathbf{1 0 0}$ & $\mathbf{1 8 0}$ & $\mathbf{1 0 0}$ \\
\hline
\end{tabular}

$30 \%$ of users said they visit the urban forests several times a week, while $19.44 \%$ expressed to be visiting once a month. The proximity of the urban forest to the city plays role in the higher visit frequency of users in Bartın and Karabük, while $26.67 \%$ of the users in Safranbolu Urban Forest said they prefered to visit the urban forest once a month (Table 9). Stojanova (2012) had similarly revealed that the users of Skopje Vodno Park prefered to visit the park 3-4 times a week (p. 29).

Table 9. Urban forest usage frequency

\begin{tabular}{lrrrrrrrr}
\hline \multirow{2}{*}{ Usage frequencey } & \multicolumn{2}{c}{ Bartın UF } & \multicolumn{2}{c}{ Karabük UF } & \multicolumn{2}{c}{ Safranbolu UF } & \multicolumn{2}{c}{ Total } \\
\cline { 2 - 10 } & Fr & $\mathbf{\%}$ & Fr & $\mathbf{\%}$ & Fr & \% & Fr & \% \\
\hline Several times a week & 20 & 33.33 & 28 & 46.67 & 6 & 10 & 54 & 30.00 \\
\hline Once a week & 19 & 31.67 & 5 & 8.33 & 6 & 10 & 30 & 16.67 \\
\hline Once in two weeks & 4 & 6.67 & 3 & 5 & 8 & 13.33 & 15 & 8.33 \\
\hline Once a month & 6 & 10.00 & 13 & 21.67 & 16 & 26.67 & 35 & 19.44 \\
\hline Once in three months & 6 & 10.00 & 2 & 3.33 & 12 & 20 & 20 & 11.11 \\
\hline Once a year & 5 & 8.33 & 9 & 15 & 12 & 20 & 26 & 14.44 \\
\hline \multicolumn{1}{c}{ TOTAL } & $\mathbf{6 0}$ & $\mathbf{1 0 0}$ & $\mathbf{6 0}$ & $\mathbf{1 0 0}$ & $\mathbf{6 0}$ & $\mathbf{1 0 0}$ & $\mathbf{1 8 0}$ & $\mathbf{1 0 0}$ \\
\hline
\end{tabular}

$66.11 \%$ of the surveyed users expressed that they visit the urban forest on the weekends (Table 10). Urban forest users who were surveyed during the weekdays also indicated that they usually visit the urban forests on the weekends. The visitor profile of mainly students and civil servants explains this situation. $33.89 \%$ of those surveyed were mostly retirees and housewives living close to the urban forests. These users expressed that they frequent the urban forest during the workdays as well. Akbaba (2007) had determined that $66.4 \%$ of the users of Kahramanmaraş Urban Forest prefered the weekend (p. 35). 
Table 10. Weekday and weekend preferences of users

\begin{tabular}{crrrrrrrr}
\hline \multirow{2}{*}{ During the week } & \multicolumn{2}{c}{ Bartın UF } & \multicolumn{2}{c}{ Karabük UF } & \multicolumn{2}{c}{ Safranbolu UF } & \multicolumn{2}{c}{ Total } \\
\cline { 2 - 10 } & Fr & $\mathbf{\%}$ & Fr & \% & Fr & \% & Fr & \% \\
\hline Weekday & 22 & 36.67 & 24 & 40 & 15 & 25 & 61 & 33.89 \\
\hline Weekend & 38 & 63.33 & 36 & 60 & 45 & 75 & 119 & 66.11 \\
\hline TOTAL & $\mathbf{6 0}$ & $\mathbf{1 0 0}$ & $\mathbf{6 0}$ & $\mathbf{1 0 0}$ & $\mathbf{6 0}$ & $\mathbf{1 0 0}$ & $\mathbf{1 8 0}$ & $\mathbf{1 0 0}$ \\
\hline
\end{tabular}

$44.44 \%$ of the surveyed have indicated that they especially prefered to use the urban forest during mid-afternoon. On the other hand, $40.56 \%$ of the users prefered to use the urban forests at noontime (Table 11). When the urban forests were separately evaluated, it was observed that the users visit Safranbolu urban forest mostly during noon. The urban forest that is used the least $(6.67 \%)$ in the morning was found out to be Bartın urban forest.

Table 11. Visit preferences of users during the day

\begin{tabular}{lrrrrrrrr}
\hline \multirow{2}{*}{ During the day } & \multicolumn{2}{c}{ Bartın UF } & \multicolumn{2}{c}{ Karabük UF } & \multicolumn{2}{c}{ Safranbolu UF } & \multicolumn{2}{c}{ Total } \\
\cline { 2 - 10 } & Fr & $\mathbf{\%}$ & Fr & \% & Fr & \% & Fr & \% \\
\hline Morning & 4 & 6.67 & 11 & 18.33 & 12 & 20.00 & 27 & 15.00 \\
\hline Noon & 25 & 41.67 & 19 & 31.67 & 29 & 48.33 & 73 & 40.56 \\
\hline Mid-afternoon & 31 & 51.67 & 30 & 50.00 & 19 & 31.67 & 80 & 44.44 \\
\hline \multicolumn{1}{c}{ TOTAL } & $\mathbf{6 0}$ & $\mathbf{1 0 0}$ & $\mathbf{6 0}$ & $\mathbf{1 0 0}$ & $\mathbf{6 0}$ & $\mathbf{1 0 0}$ & $\mathbf{1 8 0}$ & $\mathbf{1 0 0}$ \\
\hline
\end{tabular}

$56.11 \%$ of the users expressed that they spend 1 to 3 hours in the urban forests, while $23.89 \%$ spend 4 to 5 hours (Table 12). Tolunay et al. (2004) had revealed that in
Gölcük Nature Park (Isparta) 29.3\% of the users of spend 5-6 hours, and $40.6 \%$ spend 78 hours (p. 145).

Table 12. Amount of time users spend in urban forest

\begin{tabular}{lrrrrrrrr}
\hline \multirow{2}{*}{$\begin{array}{c}\text { Amount of time spent } \\
\text { during day }\end{array}$} & \multicolumn{2}{c}{ Bartın UF } & \multicolumn{2}{c}{ Karabük UF } & \multicolumn{1}{c}{ Safranbolu UF } & \multicolumn{2}{c}{ Total } \\
\cline { 2 - 11 } & Fr & \% & Fr & \% & Fr & \% & Fr & \% \\
\hline Less than 1 hour & 4 & 6.67 & 12 & 20.00 & 1 & 1.67 & 17 & 9.44 \\
\hline 1 to 3 hours & 39 & 65.00 & 38 & 63.33 & 24 & 40.00 & 101 & 56.11 \\
\hline 4 to 5 hours & 16 & 26.67 & 5 & 8.33 & 22 & 36.67 & 43 & 23.89 \\
\hline More than 6 hours & 1 & 1.67 & 5 & 8.33 & 13 & 21.67 & 19 & 10.56 \\
\hline \multicolumn{1}{c}{ TOTAL } & $\mathbf{6 0}$ & $\mathbf{1 0 0}$ & $\mathbf{6 0}$ & $\mathbf{1 0 0}$ & $\mathbf{6 0}$ & $\mathbf{1 0 0}$ & $\mathbf{1 8 0}$ & $\mathbf{1 0 0}$ \\
\hline
\end{tabular}

\section{Reasons for visiting}

$32.78 \%$ of the participants said that they come to urban forests to relax, while $22.22 \%$ come for picnicking. In addition to these, $11.11 \%$ come to take their children out and introduce them to nature, and another $11.11 \%$ come for a walk in the nature (Table 13). Similarly, users of Artvin Urban Forest expressed that they visit the urban forest primarily because of its quiet and peaceful environment, and secondly for the scenery opportunity it presents (Kurdoğlu and Düzgüneş, 2011, p. 205). On the other hand, Stojanova (2012) had determined that the users went to Skopje Vodno Park for the reasons such as walking, exercise, recreation, relaxation, and enjoying the scenery (p. 31).

When, on the other hand, urban forests are evaluated separately, it is observed that, while users visit Bartın and Karabük urban forests for relaxation, they visit Safranbolu Urban Forest for picnicking (Table 13). Low percentages of such activities as biking, photography, reading books, and exploration of nature among the reasons for visiting raises-concern. 
Table 13. Reason for visiting

\begin{tabular}{|c|c|c|c|c|c|c|c|c|}
\hline \multirow{2}{*}{ Reason for visiting } & \multicolumn{2}{|c|}{ Bartın UF } & \multicolumn{2}{|c|}{ Karabük UF } & \multicolumn{2}{|c|}{ Safranbolu UF } & \multicolumn{2}{|c|}{ Total } \\
\hline & Fr & $\%$ & Fr & $\%$ & Fr & $\%$ & $\mathbf{F r}$ & $\%$ \\
\hline To relax & 29 & 48.33 & 18 & 30.00 & 12 & 20.00 & 59 & 32.78 \\
\hline To picnic & 7 & 11.66 & 6 & 10.00 & 27 & 45.00 & 40 & 22.22 \\
\hline Taking children out and introducing nature & 5 & 8.33 & 7 & 11.66 & 8 & 13.33 & 20 & 11.11 \\
\hline Ta have long distance nature walk & 11 & 18.33 & 6 & 10.00 & 3 & 5.00 & 20 & 11.11 \\
\hline To exercise & 1 & 1.66 & 14 & 23.33 & 1 & 1.66 & 16 & 8.89 \\
\hline Other & 3 & 5.00 & 7 & 11.66 & 1 & 1.66 & 11 & 6.11 \\
\hline To collect mushrooms, fruits, and local products & 0 & 0 & 0 & 0 & 7 & 11.66 & 7 & 3.89 \\
\hline To ride bicycle & 2 & 3.33 & 0 & 0 & 0 & 0 & 2 & 1.11 \\
\hline For photography & 0 & 0 & 1 & 1.66 & 1 & 1.66 & 2 & 1.11 \\
\hline To read books & 1 & 1.66 & 1 & 1.66 & 0 & 0 & 2 & 1.11 \\
\hline To explore nature & 1 & 1.66 & 0 & 0 & 0 & 0 & 1 & 0.56 \\
\hline TOTAL & 60 & 100 & 60 & 100 & 60 & 100 & 180 & 100 \\
\hline
\end{tabular}

\section{Administration and satisfaction}

$67.78 \%$ of the users indicated that the urban forests were administered by forestry operation directorates, while $22.78 \%$ indicated municipalities (Table 14). When the urban forests are evaluated separately, a significant portion of the users from Bartin and Karabük urban forests expressed that the management of the urban forests are under the responsibility of forestry operation directorates. 50\% of Safranbolu Urban Forest users sited forestry operation directorate and $46.67 \%$ considered the municipality as the institution that administers the urban forest. In fact, at the time of the survey, Bartın Urban Forest was managed by forestry operation directorate, and Karabük Urban Forest was also managed by private individual. Administration of Safranbolu Urban Forest by the Municipality of Safranbolu, and the municipality taking the management of the urban forest seriously, contribute to this. Even then, those who sited forestry operation directorate were close to $50 \%$.

Table 14. Familiarity of urban forest administration

\begin{tabular}{lrrrrrrrr}
\hline \multirow{2}{*}{ Administration Familiarity } & \multicolumn{2}{c}{ Bartın UF } & \multicolumn{2}{c}{ Karabük UF } & \multicolumn{2}{c}{ Safranbolu UF } & \multicolumn{2}{c}{ Total } \\
\cline { 2 - 10 } & $\mathbf{F r}$ & $\mathbf{\%}$ & $\mathbf{F r}$ & $\mathbf{\%}$ & $\mathbf{F r}$ & $\mathbf{\%}$ & $\mathbf{F r}$ & $\mathbf{\%}$ \\
\hline Municipality & 5 & 8.33 & 8 & 13.33 & 28 & 46.67 & 41 & 22.78 \\
\hline Special Provincial Administration & 2 & 3.33 & 0 & 0 & 0 & 0 & 2 & 1.11 \\
\hline Forestry Operation Directorate & 48 & 80.00 & 44 & 73.33 & 30 & 50.00 & 122 & 67.78 \\
\hline District Governorship & 0 & 0 & 0 & 0 & 0 & 0 & 0 & 0 \\
\hline Private individual & 1 & 1.67 & 6 & 10.00 & 0 & 0 & 7 & 3.89 \\
\hline $\begin{array}{l}\text { Min. of Food, Agriculture and } \\
\text { Livestock Provincial Directorate }\end{array}$ & 0 & 0 & 0 & 0 & 0 & 0 & 0 & 0 \\
\hline $\begin{array}{l}\text { Min. of Environment and Urbanization } \\
\text { Provincial Directorate }\end{array}$ & 4 & 6.67 & 2 & 3.33 & 2 & 3.33 & 8 & 4.44 \\
\hline \multicolumn{1}{c}{ TOTAL } & & & & & & & & \\
\hline
\end{tabular}

When satisfaction from management was considered, $42.22 \%$ of users were unsatisfied, while $33.88 \%$ expressed satisfaction. $23.89 \%$ sited their satisfaction level as "normal" (Table 15). When urban forests are considered separately, highest level of dissatisfaction is from Bartın Urban
Forest (51.66\%). According to the observations made during conducting of the survey, the most important reason for dissatisfaction from management of urban forests is environmental pollution and extensive neglect. 
Table 15. Satisfaction from management

\begin{tabular}{lrrrrrrrr}
\hline \multicolumn{1}{c}{$\begin{array}{c}\text { Satisfaction from } \\
\text { Management }\end{array}$} & \multicolumn{2}{c}{ Bartin UF } & \multicolumn{2}{c}{ Karabük UF } & \multicolumn{2}{c}{ Safranbolu UF } & \multicolumn{2}{c}{ Total } \\
\cline { 2 - 10 } & Fr & $\mathbf{\%}$ & $\mathbf{F r}$ & $\mathbf{\%}$ & $\mathbf{F r}$ & $\mathbf{F}$ & $\mathbf{F r}$ & $\mathbf{\%}$ \\
\hline Very satisfied & 2 & 3.33 & 3 & 5.00 & 3 & 5.00 & 8 & 4.44 \\
\hline Satisfied & 18 & 30.00 & 18 & 30.00 & 17 & 28.33 & 53 & 29.44 \\
\hline Normal & 9 & 15.00 & 14 & 23.33 & 20 & 33.33 & 43 & 23.89 \\
\hline Not satisfied & 19 & 31.66 & 20 & 33.33 & 14 & 23.33 & 53 & 29.44 \\
\hline Not satisfied at all & 12 & 20.00 & 5 & 8.33 & 6 & 10.00 & 23 & 12.78 \\
\hline \multicolumn{1}{c}{ TOTAL } & $\mathbf{6 0}$ & $\mathbf{1 0 0}$ & $\mathbf{6 0}$ & $\mathbf{1 0 0}$ & $\mathbf{6 0}$ & $\mathbf{1 0 0}$ & $\mathbf{1 8 0}$ & $\mathbf{1 0 0}$ \\
\hline
\end{tabular}

\section{Conclusion and Recommendations}

The perceptions and thoughts of the urban forest users regarding the resource they are utilizing shape their demands from these areas. In the study, it was revealed that the users generally perceive the urban forests as areas for picnicking or as areas that provide clean air. Nevertheless, even though the users think of urban forest as an area for picnicking, it is also expressed by the users that these areas have different from regular recreation areas.

A significant part of the users consider that the selection of the locations for the urban forest were carried out correctly. All three being right next to the residential areas, the location of sample urban forests plays major role in this result. Almost all of the users adopted the urban forests and consider them a part of the city they live in.

More than half of the users visiting the urban forests expressed that, their view of the nature have not changed since they started visiting the urban forests because they already have that vision. It is no doubt that, the cities where the urban forests selected as sample being located in the area where the forest wealth is the highest in Turkey plays a major role in why the users have this vision. On the other hand, almost all of the users believe that the urban forests positively contribute to the physical and mental development of children.

In large part, users prefer to go to the urban forests during summer and spring seasons. Almost half of the users surveyed visit the urban forest once a week. On the other hand, a majority of the users visit the urban forests on the weekend.

Almost half of the users are found to be visiting the urban forest during the day, especially at mid-afternoon, and more than half of the users are revealed to be staying for 1 to 3 hours when they go to the urban forest.

Determining the purposes of users for visiting, as much as identifying their thoughts about urban forests, plays important role in planning and governance of urban forests. The users surveyed state that they visit urban forest mostly to relax and picnic.

The most of the users surveyed are aware that the urban forests are administered by forestry operation directorates. It is certain that the reason users think that way is influenced by the existence of high amount of forest areas and high intensity of forestry activities in the cities where the urban forests are established. Nevertheless, almost half of the users surveyed state that they were not happy with how the urban forests are managed.

General Directorate of Forestry, which is responsible with the management of urban forests, does not possess a contributive management concept during the process that start from selection of urban forest location and continue with its management. As a consequence, very significant problems are encountered during the governance of urban forests. General Directorate of Forestry can only be successful if it takes into consideration the demands of the public, whether they are urban forest users or not. Identification of the expectations of the users and satisfaction of those expectations will both increase the quality of services provided in urban forests and the level of success in the governance of urban forests. Similar to what is executed for this study, General Directorate of Forestry should carry out investigations that evaluate the expectations of the public. In addition, the necessary importance should be given to the 
governance of the urban forests. Otherwise, it is inevitable for urban forests to cater for the purposes other than the ones they are established for.

\section{References}

Akbaba, A. (2007). Evaluation of Urban Forestries in Point of National Park and Forest Landscapes in Kahramanmaraş. MSc Thesis, University of Kahramanmaraş Sütçü İmam Institute of Natural and Applied Sciences, Department of Forest Engineering, Kahramanmaraș, p.73.

Atmiş, E., Özden, S. Lise, W. (2007). Urbanization pressures on the natural forests in Turkey: an overview. Urban Forestry and Urban Greening, 6(2): 8392.

Atmiş E., Günşen H.B., Yücedağ C. (2011). An evaluation on urban forests in Mediterranean region in Turkey. $1^{\text {st }}$ National Mediterranean Forest and Environment Symposium Proceedings Book, 26-28 Octaber 2011, Kahramanmaraş, Turkey, pp.78-91.

Atmiş E., Günșen H.B., Yücedağ C. and Lise W. (2012). Status, use and management of urban forestry in Turkey. Scientific Journals for Forestry of South Eastern Europe, 3(2): 69-78.

Atmiş, E. and Günşen, H.B. (2015). An Underestimated Value in Urban Life: Urban Forests. I. International Urban Studies Congress. April 16-17, 2015, Eskișehir, Turkey, pp. 246-265.

Atmiş, E., Günşen, H.B., Özkazanç, N.K., Artar, M., Çinis, F. (2015a). A Forestry Service That Cannot Reach Urban People: Urban Forests. XIV World Forestry Congress. September 7-11, 2015. Durban, South Africa.

Atmiş, E., Günşen, H.B., Özkazanç, N.K., Artar, M., Çinis, F. (2015b). Evaluation of Resources Vaules and Management Forms of Western Black Sea Region Urban Forest. IV. Socio-economic Problems Congress in Forestry. Octaber 15-17, 2015. Trabzon/Turkey. Pp. 16-28.

Atmiş, E. (2016). Development of urban forest governance in Turkey. Urban Forestry \& Urban Greening, 19 (2016): 158-166.
Atmiş, E., Günşen, H.B., Yücedağ, C., Lise, W. (2017). Factors affecting the use of urban forests in Turkey. Turkish Journal of Forestry, 18(1): 1-10

Çağlar, Y. (2004). New adventure of forestry in Turkey: "urban forestry". 9-11 April 2004, Ankara, Turkey, $1^{\text {st }}$ National Urban Forestry Congress Proceedings Book, pp. 472-481.

Çinis, F. (2016). Investigation of the user characteristics of urban forest in the western black sea region, MSc Thesis, Bartın University Graduate School of Natural and Applied Sciences Forest Engineering Department

Kiper, T. and Öztürk, A.G. (2011). Urban forest recreation and local people's awareness about example of Edirne Urban (İzzet Arseven) forest. Journal of Tekirda $\breve{g}$ Agricultural Faculty, 8(2):105118.

Kuo, F.E. and Sullivan, W.C. (2001). Aggression and violence in the inner city: effect of environment via mental fatigue. Environment and Behavior, 33(4): 543571.

Kurdoğlu, O. and Düzgüneş, E. (2011). Determination of recreational purposes and user preferences for Artvin urban forest . Artvin Çoruh University Journal of Forestry Faculty, 12 (2):199-210.

GDF. (2003). New Approach in Our Forestry "Urban Forestry". General Directorate of Forestry, Ankara, Turkey, p.24.

GDF. (2016). Statistics of Urban Forests. General Directorate of Forestry, Ankara, Turkey (15.01.2016)

Sandal, E.K. and Karademir, N. (2013). Determination of people's expectations and consciousness with adequacy of green spaces in Kahramanmaraș. Eastern Geographical Review, 18(29): 155-176.

SPO. (2000). Long Term Strategy and $8^{\text {th }}$ Development Plan (2001-2005), State Planning Organization, Ankara, TURKEY, $243 \mathrm{p}$.

Stojanova, B. (2012). Perception of visitors toward urban forests in Skopje: Case Study Park Forest Vodno. Master Thesis, University of Belgrade International Master Program in Forest Policy and Economics, Belgrade, 63 pp. 
Taylor, A.F., Wiley, A., Kuo, F.E. and Sullivan, W.C. (1998). Growing up in the inner city: gren spaces as place to grow. Environment and Behavior, 30 (1):3-27.

Tolunay, A., Alkan, H. and Korkmaz, M. (2004). Determination of Visitor Profiles in terms of recreational activities in urban forests (A case study on Gölcük Natural Park). 9-11 April 2004, Ankara, Turkey, $1^{\text {st }}$ National Urban Forestry Congress Proceedings Book, pp.137-149

UEI. (2008). State of the urban forest: a summary of the extent and condition of Boston's urban forest. Urban Ecology Institute, Boston, USA, 51p.

Uzun, A., Ekşi, M. and Aktaş, Y. (2007). Urban forests and their importance in terms of noise control. Bottlenecks, Solutions, and Priorities in The Context of Functions of Forest Resources Proceedings of poster presentations, 1719 October 2007, İstanbul, Turkey, p.355361.

Zhao, M., Kong, Z., Escobedo, F.J. and Gao, J. (2010). Impacts of urban forest on offsetting carbon emissions from industrial energy use in Hangzhou, China. Journal of Environmental Management, 91: 807-813.

Zhu, P. and Zhang, Y. (2008). Demand for urban forest in United States Cities. Landscape and Urban Planning, 84: 293300. 